\title{
PENGARUH PEMBERIAN PUPUK KANDANG AYAM DAN KOMPOS JERAMI SERTA APLIKASI PUPUK HAYATI BIO MAX GROW (BMG) PADA PERTUMBUHAN DAN PRODUKSI TANAMAN MENTIMUN (Cucumis sativus L.)
}

\section{THE EFFECT OF CHICKEN MANURE AND STRAW COMPOST FERTILIZER WITH BIOFERTILIZER BIO MAX GROW (BMG) APPLICATION ON THE GROWTH AND PRODUCTION OF CUCUMBER PLANT}

\author{
Sarah Rahmanda Putri' ${ }^{1}$ Kus Hendarto ${ }^{2}$, Agus Karyanto ${ }^{2}$, Yohannes C. Ginting ${ }^{2}$ \\ 1. Mahasiswa Jurusan Agroteknologi Fakultas Pertanian Universitas Lampung \\ 2. Dosen Jurusan Agroteknologi Fakultas Pertanian Universitas Lampung \\ Jl. Prof. Dr. Soemantri Brojonegoro No. 1 Bandar Lampung 35145 \\ Email : sarahrahmanda98@gmail.com
}

\begin{abstract}
Fertilization by using organic materials and the addition of biological fertilizers can affect vegetable production. The research aims to determinethe effect of giving organic material and biological fertilizer that used on length of plant, number of leaves, number of branches, number of flowers, number of fruits, length of fruit, diameter of fruit, fruit weights of cucumber plant. The organic material used ischicken manure (20 tons / ha), straw compost (20 tons / ha) and BMG $0 \mathrm{ml} / \mathrm{l}, 10 \mathrm{ml} / \mathrm{l}$, and $20 \mathrm{ml} / \mathrm{l}$. This research was conducted at Sukabanjar Village, Gedong Tataan District, Pesawaran Regency on October 2018 January 2019. This research uses a Randomized Block Design (RBD) that are arranged in factorial (3x3) with 3 replications as a group and there were 9 treatment combinations. The results showed that the treatment of chicken manure with biological fertilizer BMG application on each dose has no real effect on the growth of cucumber plants, but produces the highest and better production than other treatments. Although the treatment of straw compost is no better than chicken manure, treatment of straw compost with each dose of BMG fertilizer application produces better growth and production of cucumber plants than without treatment.
\end{abstract}

Keywords: Biofertilizer, cucumber, organic fertilizer.

\begin{abstract}
ABSTRAK
Pemupukan dengan menggunakan bahan organik dan penambahan pupuk hayati dapat mempengaruhi produksi tanaman sayuran.Penelitian ini bertujuan untuk mengetahuipengaruh pemberian bahan organik dan pupuk hayati yang digunakan pada panjang tanaman, jumlah daun, jumlah cabang, jumlah bunga betina, jumlah buah, panjang buah, diameter buah, bobot buah tanaman mentimun. Bahan organik yang digunakan adalah pupuk kandang
\end{abstract}


ayam (20 ton/ha), kompos jerami (20 ton/ha) dan pupuk hayati Bio Max Grow (BMG) 0 ml/1, 10 ml/1, dan 20 ml/l. Penelitian ini dilaksanakan di Desa Sukabanjar, Kecamatan Gedong Tataan, Kabupaten Pesawaran pada Oktober 2018 - Januari 2019. Penelitian ini menggunakan Rancangan Acak Kelompok (RAK) yang disusun secara faktorial (3x3) dengan tiga ulangan sebagai kelompok dan terdapat 9 kombinasi perlakuan.Hasil penelitian menunjukkan bahwa perlakuan pemberian pupuk kandang ayam dengan aplikasi pupuk hayati BMG pada masingmasing dosis tidak berpengaruh nyata terhadap pertumbuhan tanaman mentimun, namun menghasilkan produksi yang paling tinggi dan lebih baik daripada perlakuan lainnya. Meskipun perlakuan pupuk kopos jerami tidak lebih baik daripada pupuk kandang ayam, perlakuan pupuk kompos jerami dengan masing-masing dosis aplikasi pupuk BMG menghasilkan pertumbuhan dan produksi tanaman mentimun yang lebih baik dibanding tanpa perlakuan.

Kata Kunci : Mentimun, pupuk hayati, pupuk organik.

\section{PENDAHULUAN}

Menurut Sumpena(2001) mentimun adalah salah satu sayuran yang banyak dikonsumsi oleh masyarakat Indonesia.Nilai gizi mentimun cukup baik karena sayuran buah ini merupakan sumber mineral dan vitamin. Kandungan nutrisi per 100 gram mentimun terdiri dari 15 kalori, 0,8 gram protein, 0,1gram pati, 3 gram karbohidrat, 30 miligram fosfor, 0,5 miligram besi, 0,02 miligram thianin, 0,01 miligram riboflavin, 14 miligram asam, 0,45 IU vitamin A, 0,3 IU vitamin B1 dan 0,2 IU vitamin B2.

Badan Pusat Statistik (2018) memperoleh data bahwa telah terjadi penurunan terhadap produksi mentimun di Indonesia dari tahun 2014 hingga 2017 yaitu 477.989 ton, tahun 2015 yaitu 447.696 ton, tahun 2016 yaitu 430.219 ton dan tahun 2017 yaitu 424.933 ton, penurunan produksi mentimun ini disebabkan oleh terus menurunnya luas panen tanman mentimun, sedangkan di provinsi Lampung produksi mentimun mengalami fluktuasi dari tahun 2015 hingga tahun 2018. Pada tahun 2015 produksi mentimun di Lampung yaitu
15.651 ton, tahun 2016 yaitu 16.493 ton, tahun 2017 yaitu 14.238 ton, tahun 2018 yaitu 10.601 ton.

Pemupukan adalah salah satu pemeliharaan yang utama untuk mendapatkan hasil yang optimal.Peranan suplai unsur hara untuk tanaman menunjukkan manfaat yang besar dalam meningkatkan pertumbuhan dan produksi mentimun.Kecenderungan petani untuk saat ini adalah menggunakan pupuk kimia (anorganik) karena alasan kepraktisannya. Padahal penggunaan pupuk anorganik mempunyai beberapa kelemahan yaitu antara lain harga relatif mahal, dan penggunaan dosis yang berlebihan dapat menyebabkan pencemaran lingkungan serta dapat menyebabkan produktivitas lahan menurun apabila digunakan secaraterus menerus (Fefiani dan Barus, 2014).

Adapun fungsi dari pupuk organik menurut (Setiawan, 2010) sebagai berikut: (1) sebagai operator, yaitu memperbaiki struktur tanah;(2) sebagai penyedia sumber hara makro dan mikro;(3) menambah kemampuan tanah dalam menahan air;(4) menambah kemampuan tanah untuk menahan unsur-unsur hara 
(melepas hara sesuai kebutuhan tanah); (5) sumber energi bagi mikroorganisme.

Pupuk hayati berfungsi sebagai starter sehingga proses dekomposisi pupuk organik yang di aplikasikan kedalam tanah dapat dipercepat. Secara umum, pupuk hayati memberikan alternatif yang tepat untuk memperbaiki, meningkatkan dan mempertahankan kualitas tanah sehingga mampu meningkatkan pertumbuhan dan menaikkan hasil maupun kualitas berbagai tanaman dengan signifikan (Simarmata, 2011). Menurut Gunarto (2015), pupuk hayati Bio Max Grow mengandung mikroba, enzim dan hormon seperti mikroba pelarut fospat, mikroba selulolitik, enzim alkaline fosfatase, enzim acid fosfatase, hormon indole acetic acid, azospirillum $\mathrm{sp}$, azotocbater $\mathrm{sp}$, lactobacillus $\mathrm{sp}$, pseudomonas sp, dengan aplikasi pupuk hayati pada bahan organik diharapkan dapat membuat struktur media tanam yang baik serta menambahkan sumber hara bagi tanaman. Penggunaan pupuk hayati Bio Max Grow dapat menghemat biaya pemupukan, karena dapat mengurangi penggunaan produk pupuk anorganik $50 \%$, sehingga dapat meningkatkan hasil produksi 20\%$50 \%$.

\section{BAHAN DAN METODE}

Penelitian ini akandilaksanakan di lahan Desa Sukabanjar Kecamatan Gedong Tataan Kabupaten Pesawaran Provinsi Lampung. Penelitianakan dilaksanakan pada Oktober 2018 hingga Januari 2019. Bahan yang digunakan pada penelitian ini yaitu: benih Mentimun Komandan F1, pupuk kandang ayam, pupuk kompos jerami, pupuk hayati dengan merk dagang Bio Max Grow (BMG) dan air. Alat yang digunakan di dalam penelitian ini yaitu: cangkul, parang, ajir, tali rafia meteran, penggaris, selang air, jangka sorong, timbangan,sendok, tank sprayer, gelas ukur, gunting, pisau, dan alat tulis.

Penelitian ini menggunakan Rancangan Acak Kelompok (RAK) yang disusun secara faktorial (3x3) dengan tiga ulangan sebagai kelompok dan terdapat 9 kombinasi perlakuan. Faktor pertama yaitu bahan organik pupuk kandang ayam 20 ton/ha (P1), pupuk kompos jerami 20 ton/ha (P2) dan tanpa perlakuan (P0). Faktor kedua yaitu Pupuk hayati Bio Max Grow (BMG) 10 ml/1 (H1), pupuk hayati Bio Max Grow (BMG) $20 \mathrm{ml} / \mathrm{l}(\mathrm{H} 2)$ dan tanpa perlakuan(H0). Jumlah tanaman sampel sebanyak 40 tanaman, tiap perlakuan yang sama di tiap ulangan diambil dua sampel tanaman untuk diamati. Homogenitas ragam diuji dengan uji Bartlett dan additivitas data diuji dengan uji Tukey, kemudian data dianalisis dengan sidik ragam dan dilanjutkan dengan uji BNT pada taraf 5\%.Variabel yang diamati yaitupanjang tanaman, jumlah daun, jumlah cabang, jumlah bunga betina, jumlah buah, panjang buah, diameter buah, bobot buah per tanaman dan bobot buah per petak.

\section{HASIL DAN PEMBAHASAN}

\section{Hasil Penelitian}

Rekapitulasi hasil analisis ragam penelitian menunjukkan bahwa pemberian perlakuan jenis bahan organik, pupuk hayati dan interaksinya berpengaruh nyata terhadap beberapa variabel pengamatan. 
Perlakuan pemberian bahan organik berpengaruh nyata terhadap variabel jumlah daun $6 \mathrm{mst}$, panjang tanaman (cm) 6 mst, rerata, jumlah cabang, jumlah bunga betina, rerata bobot buah tanaman sampel, jumlah bobot perpetak, jumlah buah pertanaman sampel dan rerata panjang buah sampel. Aplikasi perlakuan pupuk hayati (BMG) berpengaruh nyata terhadap variabel pengamatan jumlah daun $4 \mathrm{mst}$, jumlah bunga betina dan jumlah bobot perpetak.interaksi antara perlakuan bahan organik dan aplikasi pupuk hayati (BMG) hanya berpengaruh terhadap jumlah bunga betina. Perlakuan pengelompokan berpengaruh pada variabel jumlah daun 4 mst, jumlah daun 6 mst, panjang tanaman 6 mst, jumlah bunga betina, jumlah bobot perpetak dan rata-rata panjang buah (Tabel 1).

\section{Pembahasan}

Bahan organik memiliki peran yang sangat penting dalam proses budidaya tanaman, masing- masing bahan organik memiliki sifat substrat dan kandungan hara yang berbeda, dengan adanya penambahan bahan organik dalam proses budidaya tanaman diharapkan dapat mendukung pertumbuhan dan produksi tanaman mentimun (Cucumis sativus L.). Untuk dapat diserap oleh akar tanaman, bahan organik harus mengalami penguraian menjadi unsur hara yang lebih sederhana dengan bantuan mikroorganisme yang berada ditanah. Pemberian pupuk hayati Bio Max Grow berfungsi sebagai dekomposer yang diharapkan mampu mempercepat proses dekomposisi bahan organik yang diberikan sehingga unsur hara yang tersedia dapat lebih cepat tersedia bagi tanaman.

Pengaruh Pemberian Bahan Organik Pupuk Kandang Ayam Dan Pupuk Kompos Jerami Terhadap Pertumbuhan dan Produksi Tanaman Mentimun

Hasil penelitian menunjukkan bahwa pemberian bahan organik berupa pupuk kandang ayam dan pupuk

Tabel 1. Rekapitulasi hasil analisis ragam pengaruh pemberian dua jenis pupuk organik (pupuk kandang dan pupuk kompos jerami) serta aplikasi pupuk hayati Bio Max Grow (BMG) dan interaksinya terhadap variabel pengamatan.

\begin{tabular}{|c|c|c|c|c|}
\hline \multirow{2}{*}{ Variabel pengamatan } & \multicolumn{2}{|c|}{ Perlakuan } & \multirow{2}{*}{ Interaksi } & \multirow{2}{*}{ Kelompok } \\
\hline & Pupuk Organik & $\mathrm{BMG}$ & & \\
\hline Panjang Tanaman $(\mathrm{cm}) 6 \mathrm{MST}$ & $* *$ & th & tn & tn \\
\hline Jumlah daun 6 MST & $* *$ & tn & tn & $*$ \\
\hline Jumlah cabang & $* *$ & tn & tn & tn \\
\hline Jumlah bunga betina & $* *$ & $* *$ & * & $*$ \\
\hline Rerata panjang buah & $* *$ & tn & tn & $*$ \\
\hline Rerata diameter buah & tn & tn & tn & tn \\
\hline Jumlah buah pertanaman & $* *$ & $* *$ & $\operatorname{tn}$ & $* *$ \\
\hline Bobot buah pertanaman & $* *$ & $* *$ & $*$ & $*$ \\
\hline Bobot buah perpetak & $* *$ & $* *$ & $* *$ & $* *$ \\
\hline
\end{tabular}

Keterangan: $\mathrm{tn}=$ tidak nyata; ${ }^{*}=$ berbeda pada Q 5\%; ${ }^{* *}=$ berbeda pada Q 1\% 
kompos jerami meningkatkan pertumbuhan dan produksi tanaman mentimun (Cucumis sativus L.) kecuali pada variabel diameter buah. Bahan organik mampu menyediakan unsur hara yang dibutuhkan oleh tanaman untuk mendukung proses pertumbuhan dan produktifitasnya, selain itu penambahan bahan organik juga berfungsi untuk memperbaiki struktur tanah dan sebagai sumber makanan bagi mikroorganisme tanah. Menurut Makarim dan Sumarno (2007) unsur hara yang terdapat di bahan organik dapat dimanfaatkan untuk menyusun makro molekul sel serta unit-unit penyusunnya seperti asam amino, asam nukleat, enzim, protein, energi kimia yang dapat memberikan pengaruh yang positif bagi pertumbuhan dan produksinya.

Pada penelitian ini bahan organik pupuk kandangayam(20 ton/ha) menunjukkan pengaruh yang lebih baik dibandingkan perlakuan pupuk kompos jerami (20 ton/ha) dan perlakuan tanpa pemberian pupuk organik.Berdasarkan analisis kandungan hara yang telah dilakukan diperoleh hasil sebagai berikut. Bahan organik pupuk kandang ayam menunjukkan potensi hasil yang paling besar dari ketiga perlakuan yang ada (Tabel 2), hal tersebut dapat terjadi karena pupuk kandang ayam memiliki kadar unsur hara $\mathrm{N}$ dan P yang lebih besar daripada pupuk kompos jerami.

Hartatik dan Widowati (2006) menyatakan bahwa pupuk kandang ayam mengandung kadar hara P yang relatif tinggi. Selain itu, pupuk kandang ayam mempunyai kelebihan dalam kecepatan penyediaan hara, seperti kadar N, P, K, dan Ca. Sifat pupuk kandang ayam yang mudah terdekomposisi membuat pupuk kandang ayam selalu memberikan respon tanaman yang terbaik pada awal musim yang pertama. Menurut Anita (2015) Bobot tajuk per tanaman caisin, pakcoi dan selada dengan perlakuan pupuk kandang ayam meningkat sebesar $205.82 \%, 184.00 \%$ dan $358.61 \%$ dibandingkan dengan kontrol. Diduga hal tersebut terjadi akibat tinggi tanaman, panjang daun, lebar daun dan jumlah daun dengan perlakuan pupuk kandang ayam lebih tinggi dibandingkan pupuk organik lainnya.Gardner, et al., (1991) menyatakan ukuran tajuk yang tinggi merupakan indikasi bahwa tanaman memprioritaskan cadangan makanan hasil fotosintesis disimpan di bagian tajuk sehingga hasil panen meningkat.

\section{Pengaruh Pemberian Pupuk Hayati Terhadap}

\section{Pertumbuhan dan Produksi Tanaman Mentimun}

Pupuk hayati sangat berperan penting dalam

proses budidaya tanaman perannya sebagai dekomposer untuk membantu menyediakan unsur hara tertentu bagi tanaman. Pada penelitian yang telah dilakukan menunjukkan bahwa aplikasi pupuk hayati BMG tidak berpengaruh nyata terhadap fase vegetatif tanaman, hal tersebut diduga dipengaruhi oleh kondisi media tanam yang dilakukan di lahan sawah sehingga menyebabkan pupuk hayati yang diaplikasikan dapat menyebar ke area yang lebih luas.Penggunaan pupuk hayati BMG hanya berpengaruh nyata pada variabel jumlah bunga betina, jumlah buah per tanmaan, bobot buah per tanaman dan bobot buah per petak.

Meskipun hanya berpengaruh nyata terhadap variabel jumlah bunga betina, bobot buah per tanaman dan bobot buah per petak tanaman mentimun, aplikasi pupuk hayati BMG menghasilkan produksi yang lebih 
Tabel 2. Kandungan hara pupuk kandang ayam dan pupuk kompos jerami yang digunakan

\begin{tabular}{lccccc}
\hline Jenis Bahan Organik & $\mathrm{C} \%$ & $\mathrm{~N} \%$ & $\mathrm{P} \%$ & $\mathrm{~K} \%$ & $\mathrm{C} / \mathrm{N}$ \\
\hline Pupuk Kandang Ayam & 13,11 & 3,22 & 9,34 & 0,218 & 4,07 \\
\hline Pupuk Kompos Jerami & 16,64 & 1,78 & 1,50 & 0,372 & 9,17 \\
\hline
\end{tabular}

baik dibandingkan tanpa aplikasi pupuk hayati BMG.Hal ini diduga karena aplikasi BMG dapat meningkatkan kesuburan tanah.Efektifitas dari suatu biofertilizer dalam meningkatkan pertumbuhan dan produksi tanaman sangat tergantung pada keunggulan karakter fungsional, kepadatan populasi, kecocokan dengan tanaman inang, kecocokan lingkungan, dan daya saing inokulan (Husen, 2009).

Pengaruh Interaksi Pemberian Bahan Organik dan Pupuk Hayati terhadap Pertumbuhan dan

\section{Produksi Tanaman Mentimun}

Hasil analisis sidik ragam yang telah dilakukan (Tabel 4) menunjukkan bahwa terjadi interaksi antara perlakuan bahan organik baik pupuk kandang ayam maupun pupuk kompos jerami dengan pupuk hayati BMG terhadap variabel jumlah bunga betina, bobot buah per tanaman dan bobot total per petak.Adanya interaksi antara pemberian bahan organik dan pupuk hayati dapat menyebabkan meningkatnya jumlah unsur hara yang dapat diserap oleh tanaman melalui penguraian yang telah dilakukan mikroorganisme tanah. Penelitian ini menunjukkan produksi buah mentimun paling tinggi yang diperoleh berdasarkan bobot buah per petak berukuran $1,5 \mathrm{~m}^{2}$ dan dikalikan $80 \%$ luas lahan yang ditanami adalah pada perlakuan bahan organik pupuk kandang ayam dengan aplikasi BMG $20 \mathrm{ml} / \mathrm{l}$ adalah sebesar 40,47 ton/ha, sedangkan bahan organik pupuk kompos jerami dengan dosis BMG 20 $\mathrm{ml} / 1$ menghasilkan produksi 23,86 ton/ha. Kedua perlakuan tersebut menghasilkan jumlah bobot buah yang lebih besar daripada tanpa pemberian perlakuan bahan organik dengan dosis BMG $20 \mathrm{ml} / \mathrm{l}$ yang hanya menghasilkan 19,73 ton/ha.

Berdasarkan hasil produksi buah mentimun yang telah diperoleh menunjukkan bahwa bobot produksi buah mentimun dipengaruhi oleh jenis bahan organik dan dosis pupuk hayati BMG.Terjadinya interaksi antara pemberian bahan organik dengan pupuk hayati diduga karena adanya hubungan timbalbalik yang saling mempengaruhi antara kedua faktor sehingga mampu mendukung produksi mentimun secara maksimal.

Hasil analisis sampel bahan organik yang digunakan (Tabel 12) dapat dilihat bahwa kandungan beberapa unsur hara pada pupuk kompos jerami lebih besar dibanding pupuk kandang ayam, namun pertumbuhan dan produksi tanaman mentimun pada perlakuan pupuk kandang ayam dengan aplikasi pupuk hayati BMG menunjukkan hasil yang lebih baik. Hal tersebut diduga bahwa pupuk kandang ayam lebih cepat terdekomposisi dibanding pupuk kompos jerami, pupuk kompos jerami memiliki serat yang lebih besar sehingga membutuhkan waktu untuk terdekomposisi dan dapat diserap oleh akar tanaman dengan baik. 
Pupuk kandang ayam memiliki unsur hara $\mathrm{N}$ dan $\mathrm{P}$ yang lebih tinggi dibanding pupuk kompos jerami, hal tersebut menyebabkan mikroorganisme yang terdapat pada pupuk hayati BMG mampu membantu proses dekomposisi bahan organik

Mikroba tanah banyak berperan dalam penyediaan maupun penyerapan unsur hara bagi tanaman yang salah satunya adalah bakteri pelarut fosfat (phosphate solubilizing bacteria $=$ PSB). Bakteri pelarut fosfat merupakan kelompok mikroba yang mengubah fosfat tidak larut dalam tanahmenjadi bentuk yang dapat larut dengan jalan mensekresikan asam organik seperti asam format, asetat, propionat, laktat, glikolat, fumarat, dan suksinat (Subba Rao 1982).Bakteri tersebut menghasilkan vitamin dan fitohormon yang dapat memperbaiki pertumbuhan akar tanaman dan meningkatkan serapan hara (Glick 1995).Lebih lanjut Sutanto (2002) menyatakan N total yang terdapat pada kompos dapat menjadi energi dan makanan bagi mikroorganisme, seperti bakteri.Maka, semakin tinggi kandungan $\mathrm{N}$ total pada kompos, semakin tinggi aktivitas mikroorganismenya.

\section{KESIMPULAN}

Simpulan dari penelitian ini adalah:

1. Perlakuan pupuk organik kandang ayam memberikan hasil yang terbaik pada jumlah daun minggu ke-6 $(32,11)$, panjang tanaman minggu ke-6 $(165,67 \mathrm{~cm})$, rata-rata jumlah cabang primer minggu ke-6 $(2,72)$, jumlah bunga betina $(8,78)$ jumlah buah $(7,56)$, dan bobot buah per tanaman (1134,38 gram) dan bobot buah per plot (4968,85 gram).

2. Pemberian pupuk hayati memberikan hasil yang terbaik pada jumlah bunga betina $(7,44)$, jumlah buah $(6,00)$ bobot buah per tanaman $(913,85$ gram $)$ bobot buah per plot (3527,44 gram).

3. Interaksi padaperlakuan pupuk organik kandang ayam dan pupuk hayati menunjukkan hasil yang terbaik pada jumlah bunga betina $(10,50)$, bobot buah pertanaman (1486.33 gram) dan bobot buah perpetak (6061,82 gram).

\section{UCAPAN TERIMA KASIH}

Penulis mengucapkan terima kasih kepada pembimbing, teman-teman dan pihak lain yang telah membantu saya dalam menjalankan penelitian ini hingga selesai.

\section{DAFTAR PUSTAKA}

Anita, M. Anas D. Susila dan J. G. Kartika.2015. Pengaruh Jenis Pupuk Organik terhadap Pertumbuhan dan Hasil, Panen Tanaman Sayuran di dalam Nethouse.Bul. Agronomi. 3(2): 263-275.

Badan Pusat Statistik. 2017. Tanaman Hortikultura: Tabel Hasil Produksi Tanaman Ketimun Indonesia . https://www.bps.go.id/site/result Tab diakses pada tanggal: 5 Juli 2019 pukul 20.40

Fefiani, Y., dan W.A. Barus. 2014. Respon Pertumbuhan dan Produksi Tanaman Mentimun (Cucumis sativus L.)Akibat Pemberian Pupuk Kandang Sapi dan Pupuk Anorganik Padat Supernasa.Jurnal Agrium 19(1): 21-30. 
Gardner, F. P., R. B. Pearce, dan R. L. Mitchell. 1991. Fisiologi Tanaman Budidaya. Jilid Pertama. Penerjemah: Herawati Susilo. UI-Press. Jakarta.

Glick B.R. 1995. The Enhancement of Plant Growth by Free-Living Bacteria.J. Microbiol. 4(1): 109-117.

Gunarto, L. 2015. Bio Max Grow Tanaman. Kementrian Pertanian Republik Indonesia. Jakarta.

Hartatik, W. dan L.R. Widowati.2005.Pengaruh Kompos Pupuk Organik yang Diperkaya dengan Bahan Mineral dan Pupuk Hayati terhadap Sifat-sifat Tanah, Serapan Hara, dan Produksi Sayuran Organik.Laporan Proyek Program Pengembangan Agribisnis. Balai Penelitian Tanah. TA2005

Husen, E. 2009.Telaah Efektifitas Pupuk Hayati Komersial dalam Meningkatkan Pertumbuhan Tanaman. Balai Penelitian Tanah. Bogor

Makarim, A.K., Sumarno, dan Suyamto. 2007. Jerami Padi: Pengelolaan dan Pemanfaatan. Pusat Penelitian dan Pengembangan Tanaman Pangan. Bogor

Setiawan, B.S. 2010. Membuat Pupuk Kandang Secara Cepat. Penebar Swadaya. Jakarta.

Shantaram, S. dan A.K. Matto. 1997. Enhancing Biological Nitrogen Fixation: An Apprasial of Current and Alternative Technologies for $\mathrm{N}$ Input Into Plants. Plant and Soil. Vol. 194: 205-216.
Subba Rao, N.S. 1982. Biofertilizers in Agriculture. Oxford dan IBH Publising Co, New Delhi

Sumpena, U. 2001. Budidaya Mentimun Intensif. Jakarta. Penebar Swadaya.

Sutanto, R. 2002. Penerapan Pertanian Organik. Kanisius. Yogyakarta

Wolf, B. dan G.H. Snyder. 2003. Sustainable Soils: The Place of Organic Matter in Sustaining Soils and Their Productivity. The Haworth Press Inc. America (USA). 